HSTC Bulletin

Journal of the History of Canadian Science, Technology and Medecine

hstc

Revue d'histoire des sciences, des techniques et de la médecine au Canada

bulletin

\title{
Editorial: After One Year
}

Volume 1, numéro 4 (4), august 1977

URI : https://id.erudit.org/iderudit/1082407ar

DOI : https://doi.org/10.7202/1082407ar

Aller au sommaire du numéro

Éditeur(s)

HSTC Publications

ISSN

0228-0086 (imprimé)

1918-7742 (numérique)

Découvrir la revue

Citer ce document

(1977). Editorial: After One Year. HSTC Bulletin, 1(4), 1-1.

https://doi.org/10.7202/1082407ar

All Rights Reserved ( C Canadian Science and Technology Historical Association / Ce document est protégé par la loi sur le droit d'auteur. L’utilisation des Association pour l'histoire de la science et de la technologie au Canada, 1977 services d'Érudit (y compris la reproduction) est assujettie à sa politique d'utilisation que vous pouvez consulter en ligne.

https://apropos.erudit.org/fr/usagers/politique-dutilisation/

Cet article est diffusé et préservé par Érudit.

Érudit est un consortium interuniversitaire sans but lucratif composé de l’Université de Montréal, l'Université Laval et l'Université du Québec à

Montréal. Il a pour mission la promotion et la valorisation de la recherche.

https://www.erudit.org/fr/ 

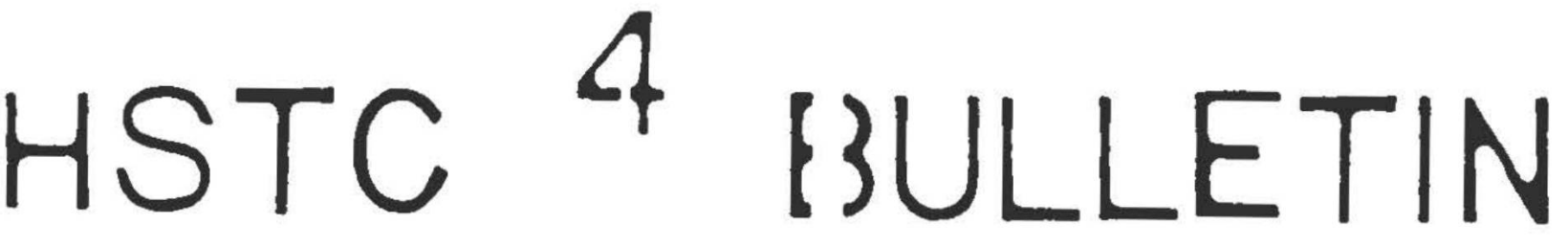

August 1977

Quarterly Newsletter for the History of Science and Technology of Canada
Publication trimestrielle pour l'histoire des sciences et de la technologie canadiennes

Editors/Redacteurs: Richard A. Jarrell (York University): Norman R. Ball (Public Archives)

Mailing Address: Dept. Natural Science, Atkinson College, York University, Downsview, Ontario M3J 2R7

\section{EDITORIAL: AFTER ONE YEAR}

With this issue, the HSTC Bulletin marks the end of its first year. The editors are extremely pleased that each issue managed to get out on time and that we are solvent. As we prepare for our second year of publication, we would like to thank all those who have helped us by providing material, financial assistance, and encouragement. We have had more material for each issue than we could print and look forward to much more as the Bulletin reaches new readers. While our circulation is still below 100, it has grown steadily and our readership includes non-subscribers. The interest in Canadian science and technology is wider than we initially assumed and this is a heartening sign.

We will continue our efforts and hope to expand our scope, but this will depend upon you, our readers. If finances allow, we also hope to print the Bulletin in a more handsome format, but for this, too, we must rely upon support.

\section{AT THE MEETINGS}

Annual Meeting of the Canadian Society for History and Philosophy of Science.

The annual meeting of CSHPS/SChPS was held at the University of New Brunswick on 28-30 May 1977. The history of Canadian science and technology was prominent in the programme, with two paper sessions and a workshop. Following are the abstracts of the Canadianroriented papers: 